\title{
Çağdaş Sanatta Otoportrenin Ele Alınış Biçimleri
}

\author{
The Forms of Self-Portrait in Contemporary Art
}

\section{Sehran Dilmaç}

Dr., Erzurum İl Milli Eğitim Müdürlüğü, sehran1981@gmail.com

\section{$\ddot{O} \mathbf{z}$}

Kendini ifade etme pratiği olarak nitelendirdiğimiz otoportre sanatçısının kendi varlığıyla karşılaştığı bir mecrayı gözler önüne serer. Otoportre özellikle insanoğlunun ifadesinin oluştuğu yer olan yüzünü yansıtmanın yanı sıra duygusal ve tinsel durumunu da izleyiciye aktarması bakımından diğer sanat uygulamalarına göre ayrıcalıklı bir yere sahiptir. Bu sebeple geçmişten günümüze plastik sanatlar perspektifinden baktığımızda otoportrenin sanatçı için vazgeçilmez bir anlatı dili olduğu da görürüz. Geçmişi belgeleme, kendini ifade etme, üstün ve soylu bir varlık olduğunu gösterme, kayıtlara geçmenin ötesinde günümüzde otoportrenin ele alınış biçimleri sanatçıdan sanatçıya farklılık göstermektedir. Sanatın anlamının ve işlevinin çok değişik boyutlar kazandığ çağdaş ve günümüz sanatında malzeme ve teknikte farklı medyumların kullanımıyla sanatsal üretimlerde, özellikle otoportre konulu çalışmalarda ilginç, sıradışı, sorgulayıcı, eleştirici bir tutum takınılmıştır. Sanatçı artık kendi salt görüntüsünün ötesinde bir şeyler arayıp bulmak isterken diğer taraftan da kendi içsel dünyasını, yaşantısının izlerini, sosyal politik olayları da kendisi eşliğinde sergilemek istemiştir. $\mathrm{Bu}$ çalışmanın amacı, dönemsel olarak otoportre konusunun ele alınış biçimlerini ve farklılıklarını ortaya koyarak geçmişten günümüze otoportrenin geçirmiş olduğu evrimsel süreci göstermektir. Ayrıca geçirilen bu evrimsel süreçteki malzeme, teknik ve anlatım olanaklarının çok yönlü yapısını irdelemektir.

Anahtar Kelimeler: Otoportre, Çağdaş, Sanat

\begin{abstract}
Self-portrait which we describe as the practice of self-expression reveals a medium in which its artist encounters his own existence. Self-portrait has a privileged place compared to other artistic applications in terms of reflecting the face of human being through which his expression is formed and also in terms of transferring the emotional and spiritual state to the viewer. For this reason, from the perspective of plastic arts, from the past to the present, we see that self-portrait is an indispensable narrative language for the artist. Beyond documenting the past, expressing self, showing self as superior and noble being, and recording, today, the ways in which self-portraits are handled vary from artist to artist. An interesting, unusual, questioning and critical attitude has started to be used in artistic productions, especially in the works related to self-portraits, with the use of different mediums in materials and techniques in contemporary and today's art, where the meaning and function of art has gained many dimensions. The artist wants to look for something beyond his own image, but on the other hand, he wants to show his inner world, traces of his life, and social and political events together with himself. The aim of this study is to demonstrate the evolution of the self-portrait from the past to the present by showing the differences and handling styles of the self-portrait subject periodically. The aim is also to evaluate the versatile structure of material, technical and narrative possibilities in this evolutionary process that is faced.
\end{abstract}

Keywords: Self-portrait, Contemporary, Art 


\section{Giriş}

Çok eski dönemlerden beri otoportre çalışmaları sanatçılar için vazgeçilmez bir uğraş olmuştur. İnsanlık tarihi boyunca portrenin gelişim safhalarına baktı̆̆ımızda başlangıçta sanatsal bir kaygı gütmekten uzak bir biçimde ortaya konmuştur. Genellikle kayıtlara geçme isteği, ölümsüzlük tutkusu, egemenlik kurma ihtiyacı, yönetici-soylu sınıfa ait olma ayrıcalığı ve dini inanışa bağlı olarak ölümdefin törenleri, hukuki ve ticari ilişkiler gibi nedenlerle portreye ihtiyaç duyulmuştur (Demirbulak, 2007, s. 45).

Portrenin önem kazanarak yaygınlaşması Rönesans ile birlikte gerçekleşmiş ve portre ve otoportrenin algılanış biçimi değişmeye başlamıştır. Rönesans dönemindeki bu gelişme ile ilgili olarak İskender şunları belirtmiştir;

Portreciliğin asıl gelişmeye başladığı dönem Rönesans'tır. 14.yy.da arkeolojinin bir bilim dalı olarak kabul görmesiyle birlikte eski metal paralarla (sikke) madalyonların incelenmesi ve koleksiyonlarının yapılmaya başlanması ile birlikte doğalcılığın gelişmesi, devlet büyüklerinin resmi büst ve portrelerinin yapılmasının yaygınlaşmasına yol açmıştır. Rönesans portreciliği doğalcılığın etkisi ile modelini acımasızca inceleyen bir biçimciliğe sahip olarak karşımıza çıkmaktadır. Portreciliği güç kılan özellik ise sanatçının yaratma özgürlüğü ile modelin bireysel özelliklerini yansıtma zorunluluğu arasındaki karşıtlıktır (İskender, 1997, s. 1505).

19. yüzyıla gelindiğinde ise Romantik portre anlayışında bu kişilik kendi içine kapanarak, kolayca girilemeyecek bir iç dünyayı oluşturmuştur. 1850'li yıllar portre ve otoportre için bir kırılma noktası olmuştur. Bilimde ve teknolojideki değiş̧imler, yeni icatlar hayatı etkilediği gibi sanatın gelişim sürecini de değiştirmiş̧tir. Bu önemli icatlardan biri ise fotoğraf makinesidir. Burjuvazinin kendini ölümsüzleştirme topluma benimsetme amacıyla sanatçılara vermiş oldukları siparişleri etkileyecektir. Bunun yanı sıra resmin varlığı da sorgulanmaya başlanmıştır. Delaroche'un o dönem fotoğraf makinesi ile ilgili belirttiği şu ifadelerinde resmin içinde bulunduğu durumu gösterir niteliktedir: " $\mathrm{Bu}$ yeni araç ressamların çok uzun bir sürede yoğun emek harcayarak yapabildiğini 'üstelik daha mükemmel sonuçlarla' kolayca elde edebilmesine olanak tanımaktadır" (aktaran Antmen, 2010, s. 11). $\mathrm{Bu}$ noktadan sonra otoportre ve portre sanatında bir yol ayrımına gidilerek sanatçılar için görünenin aynen resmedilmesinin ötesine geçme zorunluluğu ortaya çıkmaya başlamıştı denilebilir. Çünkü sanatçılar için her zaman farklılığını ortaya koyma isteği olmuştur. Bu süreçte Çağdaş sanat ve içinde bulunduğu ortam diğer dönemlerden farklı olarak buna izin verir niteliktedir. Ayrıca sanatçlar, zihinsel, duygusal yapıları ve yeteneklerindeki farklılıklarla kendi üslup özelliklerini belirlerler. Özellikle günümüzde sanat üretmede kullanılan malzemeler tamamen sanatçının insiyatifindedir. Sanat disiplinleri arasında da artık kesin ayrımlar söz konusu değildir. Otoportre de tarihsel süreci içerisinde değişim göstererek her sanatçı için kendinin bir anlatım diline dönüşmüştür.

\section{Yöntem}

$\mathrm{Bu}$ araştırma Betimsel bir araştırmadır. Araştırmada literatür taraması yapılmış ve dönemsel olarak sanatçılara göre otoportre konusunun ele alınış biçimleri ve farklılıkları ortaya koyularak, geçmişten günümüze otoportrenin geçirmiş olduğu evrimsel süreç gösterilmeye çalış1lmıştır. Ayrıca geçirilen bu evrimsel süreçteki, malzeme, teknik ve anlatım olanaklarının çok yönlü yapısı irdelenmiştir.

\section{Otoportrenin Anlamlandırılış Biçimi}

Sanatçının kendisini model olarak ele alması ve güzel sanatların herhangi bir dalını kullanarak (resim, heykel, fotoğraf vb.) kendi fiziksel, duygusal ve psikolojik özelliklerini ürettiği esere yansıtmasıdır (Salkur, 2014, s. 4). Ayrıca ressamın en kişisel anlatım şeklidir ve sanatsal varoluşu, sanat tarihsel 
tanınmayı güvence altına almanın sağlam bir yoludur. Otoportre ressamların düşüncesi olarak tanımlanabilen ve onların umuma sunmaya istekli olduğu sanatsal kimliğin ortaya çıkmasıdır (Demirbulak, 2007, s. 48).

Otoportre sanatında bakış ise ressamı hem harici olarak -dış dünyada, insanlar arasında kendi başına dış görünüş olarak hem de iç dünyanın kaynağına yönelik gören kişi olarak karakterize edilir (Demirbulak, 2007, s. 7). Otoportrecilik tekil ve içe dönük bir sanattır. Otoportreler çoğunlukla ifade etme ve ressamı izleyicilere takdim etme amacı taşırlar. Genellikle bakış, duruş ve ellerin hareketleri gibi yollarla, bakan kişilere hitap ederler. Otoportreler hakkında gerçekleştirilen çalışmalar, sanatsal süreçleri, kimlikleri ve sanatın içinde gerçekleştirilen düzeni hakkında fikir sahibi olmamıza yardımcı olmaktadır. Dolayısıyla "otoportre sanatının içeriğini anlamak, dilinin farkına varmak ve ona eleştirel bir yönden yaklaşmak; otoportrelerin hak ettiği değerleri vermek açısından önemli bir adımdır. Otoportreler, ressamların düşüncesi olarak tanımlanabilen ve onların umuma sunmaya istekli oldukları sanatsal kimliği büyük ölçüde ortaya çıkarırlar" (Woodal, Bond, Clark, Jordanova ve Koerner, 2005, s. 52). Kendi portresini yapan ressamın işi tamamen kişiseldir ve bazen de onu izleyen seyirci neredeyse alakasız bir duruma düşebilir. Otoportreler herhangi bir izleyici, müşterinin değil bizatihi ressamın kendi kaygılarına cevap verir. Otoportrenin ilk seyircisi de kendi kendisini işleyen ressamdır (Leppert, 2002, s. 212). Otoportre türlerini şu şekilde sıralamamız mümkündür:

- Arkadaşlar, eşler, patronlarla ya da mükemmel bir öznenin altını çizmek için alt sınıftan kişilerle birlikte çizilmiş otoportreler,

- Dünyevi zevklerin ve başarıların geçiciliğini simgeleyen kuru kafa, zayıf yanan mumlar ve kelebekler gibi sembollerden yararlanarak hayatın kırılganlığ 1 üzerinde yoğunlaşan "vanitas" türü otoportreler,

- Zenginlik ve statü belirten ve doğru müşteriyi çeken bir formül olarak seçkin ve pahalı elbiseler eşliğinde kılık değiştirerek yapılan otoportreler,

- Poz veren kişi ile tabloya bakmakta olan kişi arasında bilgi alışverişini sağlamak için gizli ya da açık simgelere yer verilen otoportreler,

- Yaşl111k otoportreleri,

- Ruhsal göndermelerle dolu otoportreler,

- Kimlik arayışı/sorgulaması içinde olan çalışmalar olarak gerçekleştirdikleri görülür (Woodal ve diğerleri, 2005, s. 53).

\section{4. Çağdaş Sanat ve Otoportre}

Yakın dönemlere kadar modern sanatın tarihi, sanat hareketlerinin kronolojik bir ilerlemesi şeklinde gösterilmiş ve öyle kavranmıştır. 1940'lı yıllarda eleştirmen Clement Greenberg, formalizm olarak bilinen savını ileri sürerek, Modern sanatın Rönesans dönemi sanat anlayışından kesin bir kopuşla bir saflık idealine doğru yol aldığını ileri sürmüştür. Greenberg'in peşinden gelen saflık anlatısına uygun düşmeyen hareketler, modern sanatın ana gelişim çizgisinden uzaklaşan ve gözardı edilen hareketler olarak algılanmıştır. Örneğin Dada, anarşik ruhu, belirgin siyasal içeriği olduğu için genellikle tuhaf bir kopuş olarak görülmüştür. Sonraları ise Pop sanatçıları ve Minimalist sanatçılar da nihai saflığa giden anlayışı reddetmişlerdi. Bu sanattaki yenilik arayışları, sanatı bir nesne olarak görmeye yanaşmazken, sanatın pazarlanabilir bir meta olma statüsüne başkaldırma ve bir sanat eserinin niteliğini yargılamayı öngören bütün mevcut ölçütleri yıkma girişiminde bulunmadır. 1970'li yıllara gelindiğinde ise sanat tarihinin form ve içeriğe dayalı yüceltilmiş standartlarını kabul etmeyerek, sanat yapmakta ne kadar ileri gidilebileceğini sorgulayan deneysel çalışmalara yönelmişlerdir. Daha sonra 
1990'lı yılların başında içinde çoğulcu anlatımların artmasıyla sanat, Post-yapısalcı teori, feminizm, Marksizim, Psikanaliz, Formalizm, Çokkültürcülük ve Analitik felsefenin bulunduğu akımlarla karakterize edilmiştir. Bu çok çeşitlikle birlikte eleştirmenlerin sanat eserlerine yaklaşımları ve tutumları da değişiklik göstermiştir. Eleştirmenler sanat eserlerini çeşitli yollarla ve çoğu durumda eşzamanlı olarak, sanatçının psiko-sosyal durumunun yansımaları, belirtileri, gösterenle gösterge arasındaki kopukluğun kanıtları ya da malzemenin içsel mantığının göreceli eski bir biçimde ortaya koyulmuş özleri olarak nitelemektedirler. Sanat artık, herşeyin bir ortak noktadan filizlendiği bir dizi gelişme şeklinde düşünülememektedir (Heartney, 2008, s. 8-12). Çağdaş sanatta bu çok çeşitlilikte birlikte malzeme kullanımında değişiklikler, gelişmeler olmuştur. $\mathrm{Bu}$ malzeme kullanımındaki değişiklikler otoportre sanatında da her sanatçı için bambaşka bir anlatı diline dönüşmüştür.

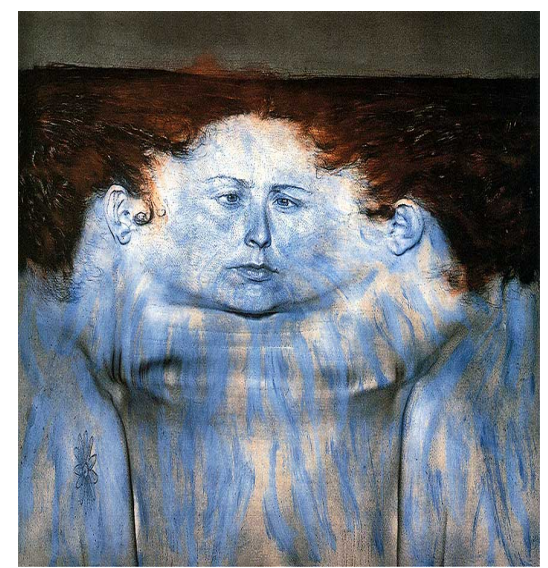

Resim1. Kiki Smith, Benim Mavi Gölüm, $106 x 134 \mathrm{~cm}$.

Smith'in 1995 yılında fotogravür ve litografi tekniği ile gerçekleştirdiği bu eserinde insan yüzü ve torsosunu bir harita gibi resmetmiştir (Resim 1). Bu eserin birkaç parçası 1990'ların başlarında sanatta kadının tasvirinin nasıl değiştiğini göstermek amacıyla yapmıştır (Kimmelman, 1996, s. 1). Smith dünya ile kendi vücudunu birleştirerek resmetmek için jeolojik özellikleri yakalama amacıyla tasarlanan bir kamera kullanmıştır. Böylece kendini adeta bir araziymiş gibi fotoğraflayabilmiştir. Baskı tekniklerinden drypoint'i kullanan sanatçı vücudunda ve saçlarında kırmızı ve mavi renkleri kullanmış ve tipografik işaretlerle ipuçları bırakmıştır. Royal Akademiden izin alarak kullandığı kamera, tüm vücudunun iki boyutlu bir görüntüsünü vermektedir. Bu yöntemde elde edilen fotoğrafta cildin görüntüsü bozulurken merkezde bulunan yüzde bu deformasyon daha az görülmektedir. İzleyicinin bakışlarını merkezde toplayan bu çalışma ile sanatçı adeta bireyin doğal dünyadaki rollerini ve ilişkilerini düşünmeye zorlanmaktadır.

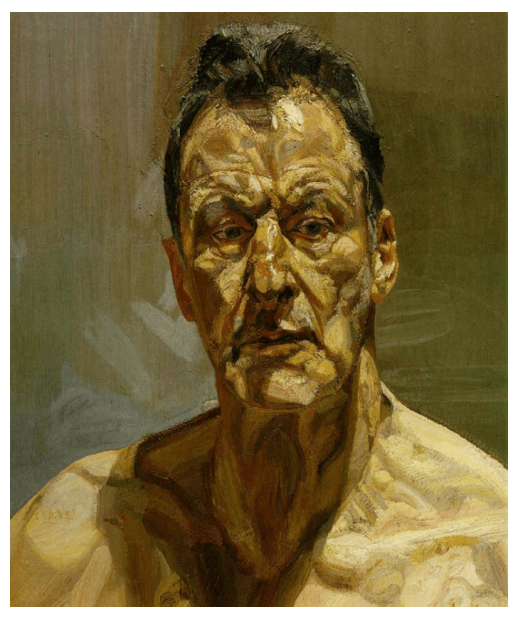

Resim 2. Lucian Freud, Otoportre. 
Freud, kendini popüler anlamda gözler önüne sürülen sanatçıların tersine, derin bir çalışma disipliniyle ilerleyen ve çağdaş sanat dünyasında yerini perçinleyen bir sanatçıdır (Resim 2). Çizimdeki başarısı eski ustaları aratmayacak nitelikte olup son derece de moderndir. Onun resimlerinde boya, boya olarak maddi varlığını korur bununla birlikte deriye, ete ve damarlara dönüşür. Bu nedenle Freud "eti en iyi resmeden sanatçı” diye ünlenmiştir (Yılmaz, 2006, s. 348).

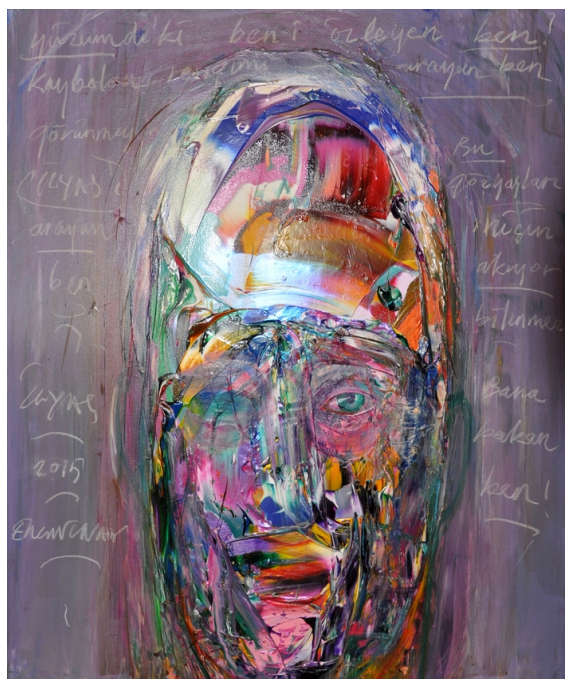

Resim 3. Ergin Inan, Otoportre, $60 \times 80 \mathrm{~cm}$.

İnan, çalışmalarında Mevlana'dan Kafka'ya uzanan, Doğu-Batı senteziyle oluşturulmuş fantastik bir dil kullanmıştır (Resim 3). İnan, dışavurumcu bir üslupla yapmış olduğu resimleriyle ilgili olarak kendi varoluşunu sorguladığını belirtmiştir. Ona göre her bireyin bir yaşam şekli ve yaşamda verili bir zaman dilimi vardır ve birey o zaman dilimi içinde kendini bir şekilde bulmaya ve ifade etmeye çalışmıştır (Yılmaz, 2017).

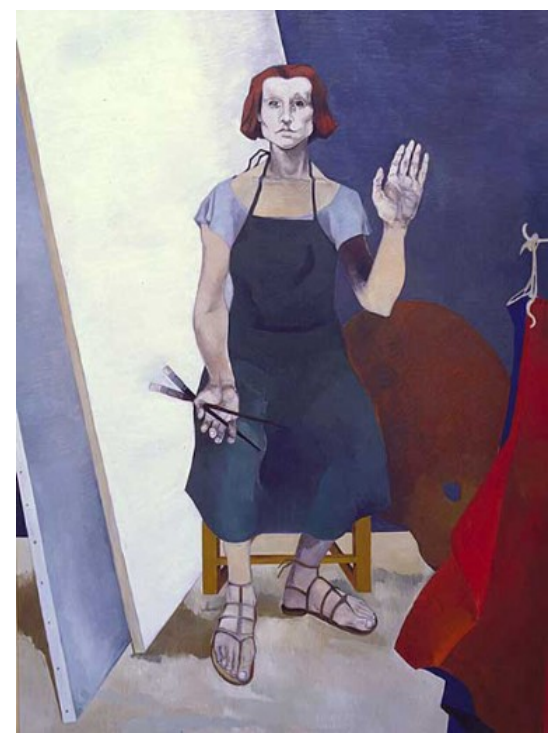

Resim 4. Neşe Erdok, Tanık, $160 \times 200 \mathrm{~cm}$.

Toplumsal içerikli portre özellikli resimlerinin yanı sıra Erdok sürekli kendi portresini çalışan bir ressamdır (Resim 4). Otoportrelerinde kendini farklı mekanlarda ve farklı şekillerde konumlandırarak kompozisyonlarını oluşturur. Erdok'un otoportreleri günlük hayatın, yaşanan sıradan anlarına yerleştirilen fakat bir bakıma o alandan ayrı gibi de duran psikolojik etkileri güçlü ve dışavurumsal niteliktedir. Erdok'un resimlerini en ilginç kılan nokta, figürün yananlamına tümüyle kendini yüklemiş 
olmasından kaynaklanmaktadır. Onun hiçbir figürü temsil ettiğinin ötesinde, dış dünyadaki karş1lığ1 ile zorunlu bir ilişkide de değildir. Çünkü Erdok için resim yapma, bu dünyaya katlanmanın tek çıkar yolu ya da psikolojik anlatım ve rahatlama aracı değil, kendi ben'inde odaklanan tepki ve sorumluluğu dile getirmek üzere bilinçle seçtiği bir ifade vesilesidir (Ergüven, 2002, s. 256).

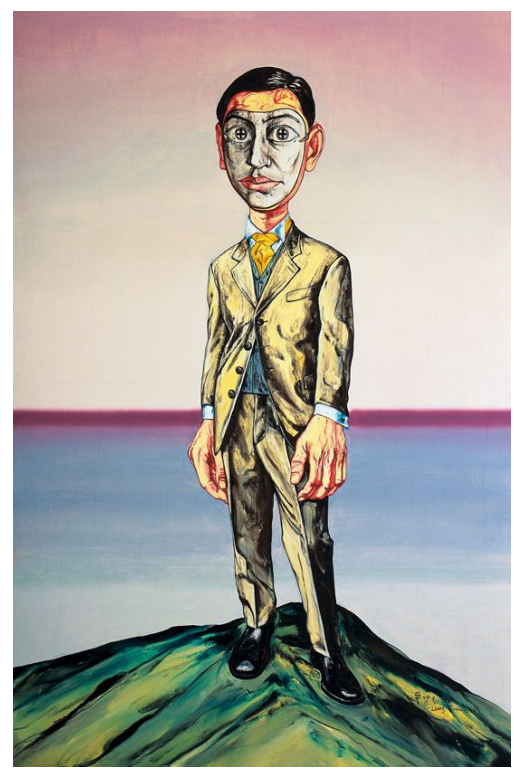

Resim 5. Zeng Fanzhi, Maske Serisi

Fanzhi’nin maske serisine baktığımızda figürün ya da figürlerin yüzüne yerleştirilmiş bariz şekilde belli bir maske görürüz (Resim 5). Maskelerin üzerindeki yüz ifadesi aslında Fanzhi'nin yüzüyle bire bir aynı ifadedir. Sanatçının da uzun bir yüzü, iri badem gözleri ve uzun bir burnu vardır. Sanatçı kendi yüzünü bir maske biçiminde betimleyerek çeşitli figürlerin üzerine konumlandırmıştır. Onun figürleri hem kendisi hem de bir başkası olsun takılı maskeler aracılığıyla kendi yüzünden, yaşanmışlıklarından hayata bakışı içerir. Kendi yüzü ve yüzlerini maske gibi göstererek hem otoportresini oluşturur hem de yaşanmışlıklarını dışavurur. Çünkü maskelerin hepsinde aynı gülen bir yüz ifadesi vardır. Sanatçı tuvalet gibi en mahrem ihtiyaçlarından birini karşılamak için bile başka bir yere gitmek zorundadır. Gittiği yer de akıl hastalarıyla dolu bir kliniktir. Bu durum onun psikolojisini derinden etkilemiştir. Belki de bu sebeple onun maske adlı serisinde yüzlere taktığg aslında her birinin kendisi olduğu mahcup, gülen ifadeli yüzleri görürüz (Kaynak, 2016, s. 156).

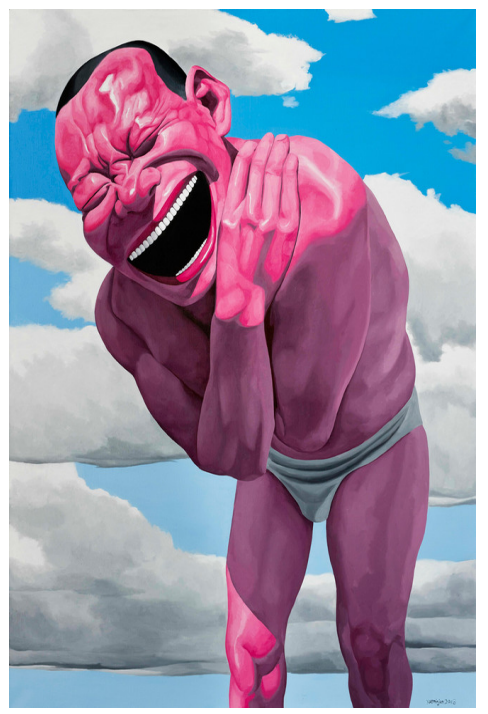

Resim 6. Yue Minjun, Mavi Gök Beyaz Bulut, 240x200cm 
Çin'in ulusal ve uluslararası ölçekte bilinen en ünlü çağdaş sanatçısı olan Minjun 1989 yılında gördüğü bir resimden etkilenerek kendi çıkış noktasını yakalamıştır. Minjun bu yıllardan sonra imzasına dönüşecek olan sırıtan yüzüne esin veren Gengy Jianyi’nin “İkinci Durum” adlı resmini görmüştü. Onun kendi yüzünü çok çeşitli şekillerde ve hallerde gülerken resmettiği çalışmaları Minjun'u derinden etkilemiştir (Resim 6). Bu etki halinde sanatçı neredeyse çenesi çıkacak ölçüde sırıtırken resmettiği kırmızı renkteki yüzüyle ve dışavurumcu üslubuyla bilinirlik kazanmıştır. Çinli sanatçıyı etkileyen bu kırmızı yüzlü sırıtışını donduran diğer bir önemli olayda Pekin'de Tiananmen Meydanında yaşanılan olaydı. Meydanda özgürlük ve demokrasiye yönelik taleplerini dile getirmek için toplanan öğrenci, işçi ve aydınlar hükümetin çok sert tepkisiyle karşılaşmış pek çok kişi hayatını yitirmiştir. Minjun'un kırmızı sırıtık yüzü, bütün bu olayları ironik bir şekilde eleştiri niteliğindedir. $\mathrm{Bu}$ olaylar sanatçının ruh halini derinden etkileyerek gerçek ile ideal arasındaki uçurumu fark etmesine sebep olmuştur. Bu olaylardan hareketle Minjun, kendi sanatsal tanımını bulmaya girişmiş ve sanatçının attığı ilk adım kendinden yola çıkarak, hislerini doğru bir şekilde dışavurumcu ifade edebileceği bir üslup geliştirmek olmuştur. Kendisini abartılı bir biçimde gülerken tasvir ettiği resimlerin çıkış noktasını bu şekilde ifade eden Minjun, gülmenin her zaman mutluluk anlamına gelmediğine de dikkat çekmek istemiştir (İz, 2014, s. 91).

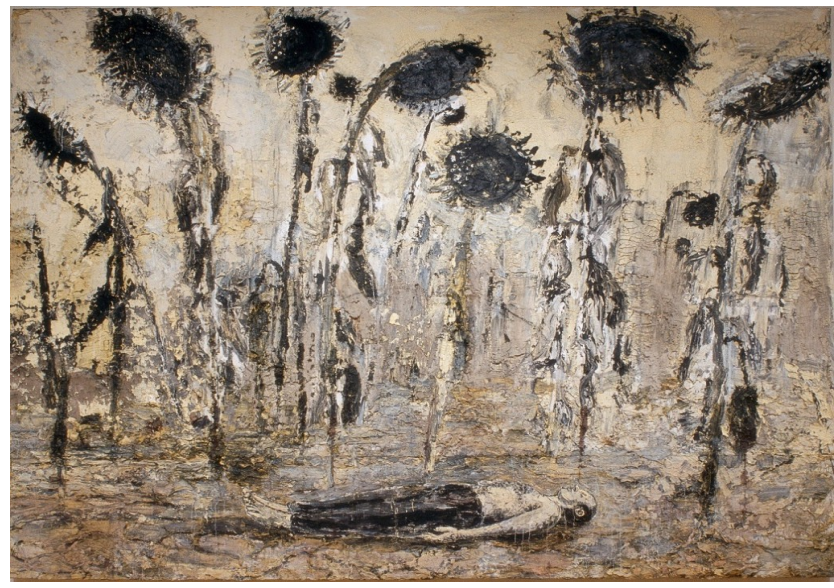

Resim 7. Anselm Kiefer, Gecenin Emirleri, $356 \times 463 \mathrm{~cm}$

Modern sanatın en önemli sanatçılarından biri sayılan Alman sanatçının yaşamı yıkıntı ve harap bitap yerler arasında geçmiştir ve çocukluğunda gördükleri, savaşın acı izleri sanatı derin bir şekilde etkilemiştir. Kiefer sanatıyla ilgili olarak "kalıntıları severim çünkü onlar, yeni bir şeylerin başlangıç noktasıdır" demiştir. Sanatçı kariyerini enkaz yığınlarını sanata dönüştürerek oluşturmuştur.

Kiefer'in resimlerinde genellikle siyah, gri, kahverengi gibi kasvetli tonları kullanmıştır ve eserleri lirik ve romantik bir dil içerir. Sanatçının Gecenin Emirleri (The Orders of The Night) adlı eseri sanatçının dışavurumcu bir otoportresi niteliğindedir (Resim 7). Kiefer, bu çalışmasında kendisini tuvalin en orta alt bölümünde yarı çılak bir halde sırtüstü bir ölü yatar gibi resmetmiştir. Kiefer'in üzerinden yükselir gibi duran boynu bükük Günebakan çiçekleri ise onun bu ölü gibi haline doğru eğilmiş onu takip ediyor gibi gözükmektedir. Kahverengi ve sarı tonlarının hakim olduğu bu çalışmadaki üst üste katmanlanmış boyalar Kiefer'in yaşanmışlıklarının, acılarının birikimi gibi durmaktadır. Sanatçının bir cenazeyi andıran yatış şekli ve üzerindeki Günebakanlar yaşamın sona erişine ve geçmişten o andaki sürece kadar olan olaylar örüntüsüne tanıklık ediyor gibi durmaktadırlar. İçinde yaşamın süreçlerini ve kesitlerini barındırıyormuş gibi duran bu çalışma sanatçının kendini ve benliğini dışavuran bir otoportre niteliğindedir (Çarmıklı, 2014). Ayrıca Van Gogh'un Ayçiçekleri serisine de gönderme yapan çalışma, ayçiçeklerinin karanlık bir tarihin parçası olarak yeniden yorumudur. Bir orman gibi yoğun olan siyah ayçiçekleri, yerde yatan Kiefer'in üzerine ölümün 
gölgesi gibi kabarık başlarıyla sarkarlar. Kiefer, Van Gogh'un neşeli, parlak, tamamen açmış çiçeklerini soyar ve sanki onları aydınlık gökyüzünün altında faziletsiz bir savaşa sürükler.

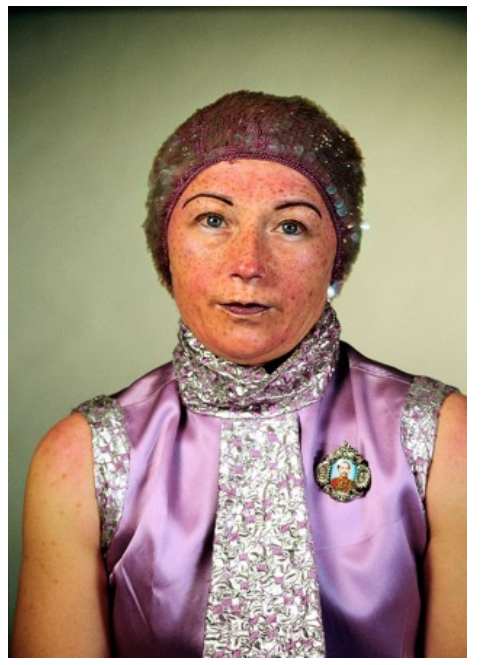

Resim 8. Cindy Sherman, İsimsiz 351.

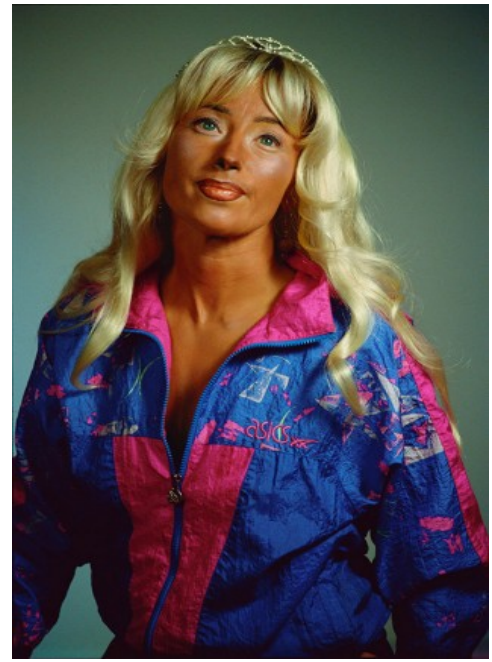

Resim 9. Cindy Sherman, İsimsiz 397.

Kendi kendini sürekli fotoğraflayan Sherman'ın yapmış olduğu çalışmaların hepsi de birer otoportre niteliğindedir. $\mathrm{O}$, otoportre fotoğraflarında birbirinden farklı değişik kimliklere bürünerek gerçek görüntüsünü gizlemeyi başarmıştır. Bu durumda kendisini model olarak kullandığı fotoğrafları birer karş1-portredir. Çünkü bir otoportreden ya da portreden beklenin aksine izleyiciye kendisiyle ilgili yanlış bilgiler verir (Yılmaz, 2006, s. 317-318). Sherman'ın sürekli olarak kendini fotoğraflayarak kendi hakkında değilde toplumda yer alan her kesimden, her meslekten türlü türlü kadını anlatması da bu durumun bir göstergesidir (Resim 8-9).

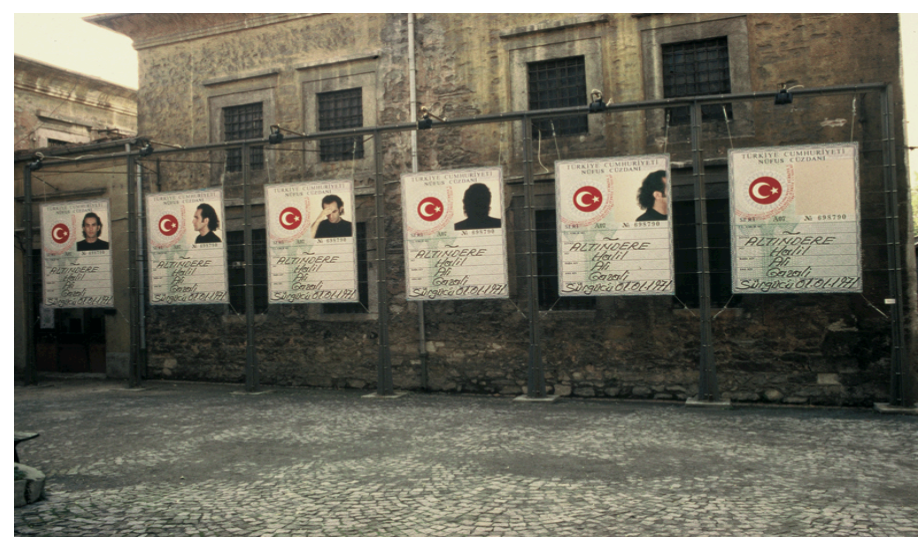

Resim 10. Halil Alttndere, Tabularla Dans

Altındere, otoportrelerinde kimlik problemini dışavurumcu bir üslupla ele alan sanatç1lardandır. O, erken dönem çalışmalarında ulus-devleti, iktidarı simgeleyen kimlik kartı, banknot, pul gibi günlük yaşamdan sıradan nesnelerin anlamlarını küçük müdahalelerle ters yüz ederken, 2000 sonrası çalışmalarında daha çok alt kültürler, gündelik yaşam içindeki sıra dışı ancak olağan görünen durumları dişavurumcu bir üslupla ifade etmiştir (Resim 10). Çalışmalarında kendi fotoğraflarını kullanarak kendi kimliğini politik ve ironik bir yaklaşımla dışavurumcu bir şekilde ifade etmiştir (Ateş, 2015). 


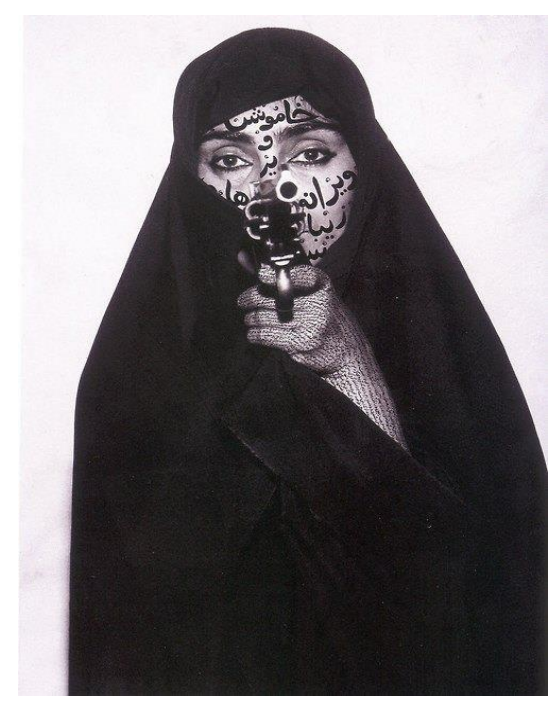

Resim 11. Şirin Neşat, Allah’ın Kadınları

İran asıllı Amerikalı sanatçı genellikle fotoğraf çalışmalarıyla tanınır. Bu çalışmalarda kendini model olarak kullanarak kendi otoportrelerini dışavurumcu bir şekilde yansıtır (Resim 11). Kendi kökeni olan doğu coğrafyasındaki yazı imgeleriyle eğitim aldığı yaşadığı batı kültürünün deneyimlerini harmanlayarak yapıtlarını ortaya koyar. Neşat'ın otoportre fotoğraflarında islam kadını teknolojik imgelerle, modern bir ortamda ifade bulmuştur. Fotoğrafların üzerinde Farsça yazılar görülmektedir. Fotoğraflara ilk bakışta, yazıların Neşat'ın figürleri üzerinde yazıldığını zannetsek bile; çalışmalara dikkatli bakıldığında, yazıların fotoğraf üzerine yazıldıklarını fark edebiliriz (Yılmaz, 2006, s. 422). Doğu toplumlarında geçmişten gelen bir gelenekle kullanılan yazı ya da resimler geçici ve kalıcı dövmelerden esinlenmiş gibi duran Neşat, kendi kökeniyle de bağlantı kurarak çalışmalarını içselleştirir. Sonuç olarak da İslam kadının hüviyeti şeklinde kendini dışavurur.

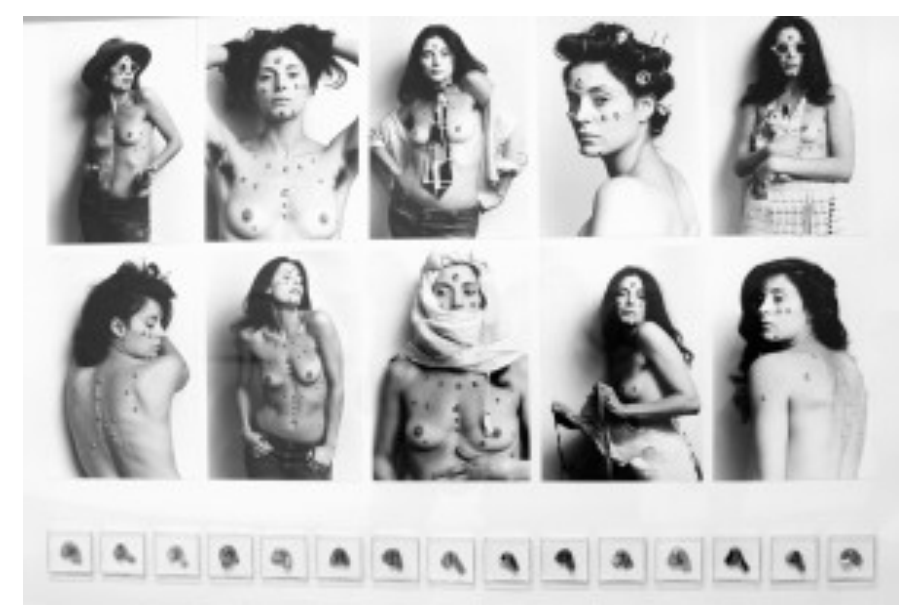

Resim 12. Hannah Wilke, Starlaştırtlan Obje Serisi

Amerikalı sanatçı Wilke, kadınlık, feminizm ve cinselliğin egemen görüşlerini incelemek ve meydan okumak için fotoğraf, performans, heykel ve videonun çeşitli araçlarını kullanmıştır. Wilke, 1950'lerin sonları ile 1970'lerin başına kadar vücuda dayalı bir tür kadın ikonografi hazırlamaya çalışmış ve kadın cinsel organına çok yakın soyut ve organik formlar üretmiştir. Bu formları zeminde veya duvarda, son derece organize ve tekrarlayan bir tarzda, Minimalizmi formu bir tarzda sergilemiştir (Resim 12).

Wilke Starlaştırılan Obje Dizisi (Starification Object Series), (1974-79) çalışmasında, kadın ünlülerin aksesuarlarını ve tutumlarını benimseyen bir dizi siyah beyaz fotoğraf hareketi için yarım çılak 
görüntüler sunmuş ve gövdesini kelimenin tam anlamıyla çürük kadın dış genital organlarıyla örülü bir alana dönüştürmüştür.

Çiğnenmiş sakızı, kadın bedenlerinin nesneleştirilmesine dikkat çekerek farkındalık yaratmak istemiştir. Böylelikle izleyicinin kadın bedenini arzu eden bakışlarını kesintiye uğratmayı isteyerek kendi otoportresi üzerinden gönderme yapmak istemiştir. Fotoğraflarında küçük vulva biçimindeki çiğnenmiş sakız parçalarıyla kaplı vücudu Geleneksel (kadınsı) arzulanabilirlik kavramlarına meydan okumak adına yaptığı çalışmalarda Wilke, kendini bütün kadınların yaşadığı sıkıntıların bir göstergesi olarak dişavurmuştur (“Collection Online”, t.y.).

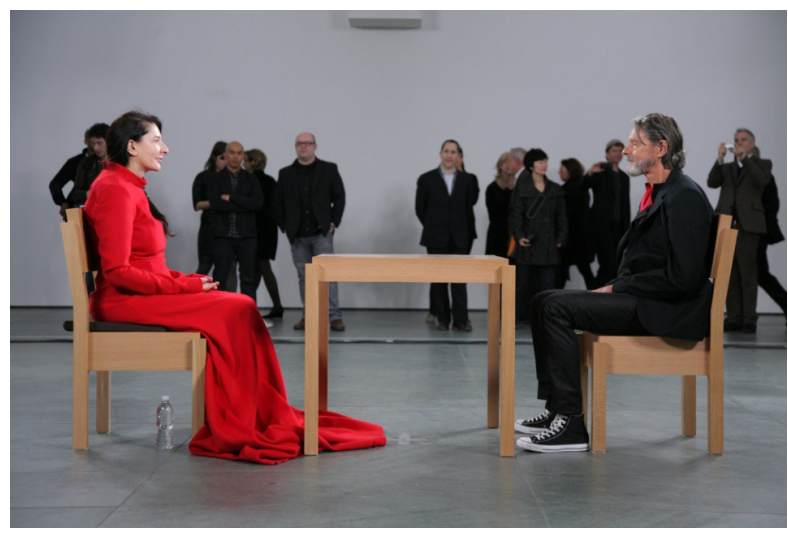

Resim 13. Marina Abromoviç, Sanatçı Aramızda

Yugoslav sanatçı Abromoviç, 2010 yılında New York Modern Sanatlar Müzesinde gerçekleştirmiş olduğu gösteride bir masanın önünde hiç hareket etmeden ve hiç bir tepki vermeden oturmaktadır. Abromoviç'in görünüşü son derece basit olan "Sanatçı Aramızda" performans sanatına özgü marjinal sınırları bütünüyle aşan, sıradışı bir gücü vardı (Resim 13). Belirli bir yerde ve zamanda insan bedeni aracılığıyla doğrudan halka hitap eden performansı anlatabilecek en iyi kelimeler "tahammül" ve "karşılaşma"dır. Abromoviç’in bugüne kadar yaptığ 1 bu en uzun tek kişilik performans ve otoportresi kabul edilen bu performans, gücün, dayanıklığın, sabrın sınırlarını ve çağrışımlarını sınamak için tasarlanmış yaratıcı bir eylemdir (Wilson, 2015, s. 14). Bu şekilde günde yedi buçuk saat oturmuştur. Fakat Marina'nın oturduğu masanın karşısına konulan sandalyede gün içinde farklı farklı insanlar farklı mesafe aralıklarıyla oturmuşlardır. Bir otobiyografi niteliğinde olan bu gösteride Abromoviç, acılarını, sevinçlerini, deneyimlerini sadece bakışlarıyla paylaşan binlerce insanla sessiz bir deneyim yaşamıştır. Böylelikle kendi duygularını sessiz duruşuyla dışavurmuştur (Yıldız, 2017).

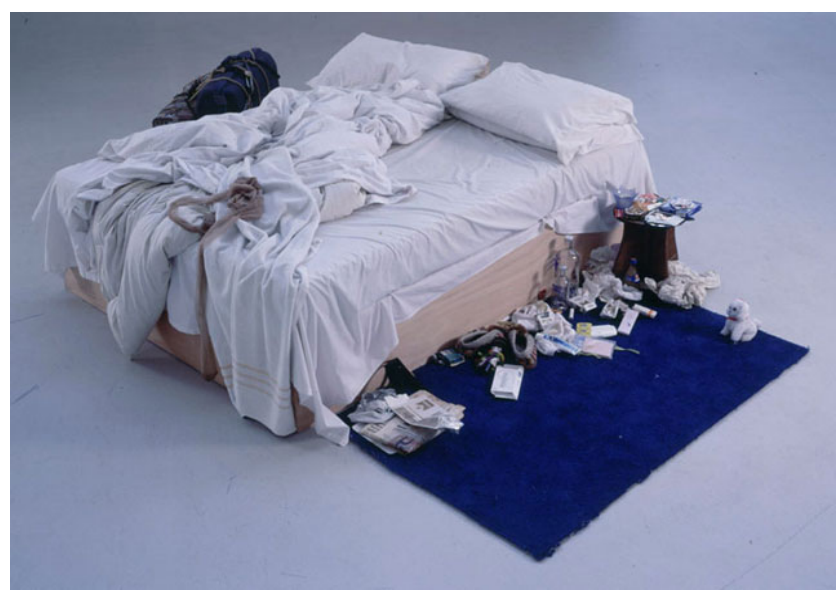

Resim 14. Tracey Emin, Benim Yată̆ım 
Emin, otobiyografik çalışmalarıyla kendini olduğu gibi ve hayatın içinde kendini bulduğu şekliyle dışavurumcu bir ifadeyle yansıtan bir sanatçıdır. Her ne kadar yüzünü kullanmasa da onun bu çalışması bir otoportre niteliğindedir (Resim 14). Emin'in sanatını en çok etkileyen olay 13 yaşındayken tecavüze uğramasıdır. Emin bu talihsiz durumuyla ilgili "bir gün hiç göğsüm yokken ertesi gün en büyük göğüs benimkiydi” yorumunu yapmıştır.

Emin'in en önemli eseri olan "Benim Yatağım" aslında sanatçının küçük yaşta yaşadığı travmanın onun hayatını çok kötü etkilediği bu yaşanmışlığıyla benliğinin darmadağın olduğunun göstergesidir. Emin bu çalışmasıyla kendi gerçeğinin otoportresini kendi bedenini kullanmadan yapmıştır (Balkaya, 2015).

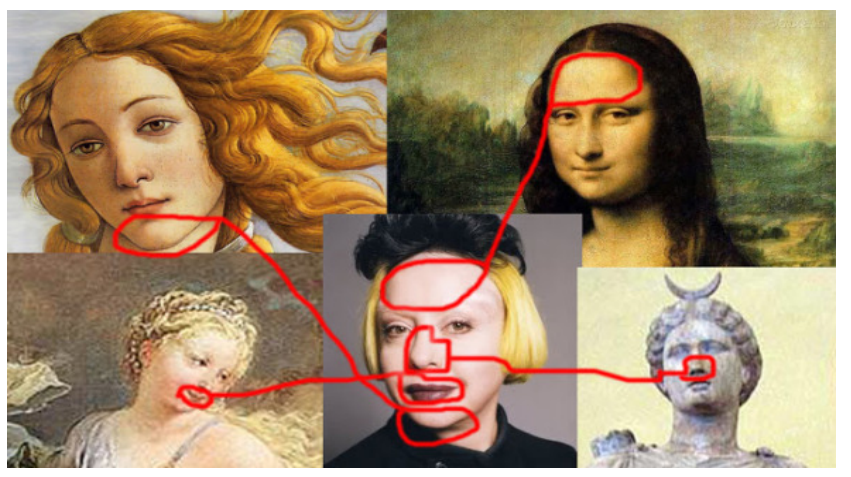

Resim 15. Orlan Carnal, Art

Orlan'ın otoportresi olarak nitelendirebileceğimiz sanat çalışmaları, kişinin sanat yaratmak için kendi bedeninin tutarlı bir şekilde kullanılmasına dayanan, ütopik bir misyona yönelik performanslarıdır (Resim 15). Şu anda 70'li yaşlarda olan Orlan, yaklaşık elli yıllık sanat hayatında bir kutsal töreni andıran seremonilerle, kendine çeşitli plastik ameliyatlar yaptırmış, kendisini narsisizm sorumluğuna açık bırakan, dikkat çeken sıradışı işler sergilemiştir. Carnal Art olarak adlandırdığı sanatsal performanslarında, erkek iktidarının güzellik kavramını ve modern batı toplumlarında kadın öznenin yapılandırılışını eleştirmek için bir dizi ameliyatla vücudunu özellikle yüzünü yeniden yapılandırarak kendini farklı farklı kimliklerle dışavurur. Orlan, güzellik kavramını da ele alarak kendi sanatıyla sorgular (Akman, 2005).

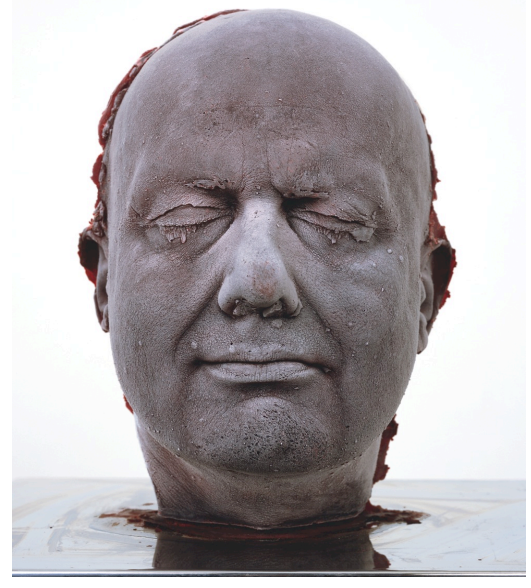

Resim 16.Marc Quinn, Self

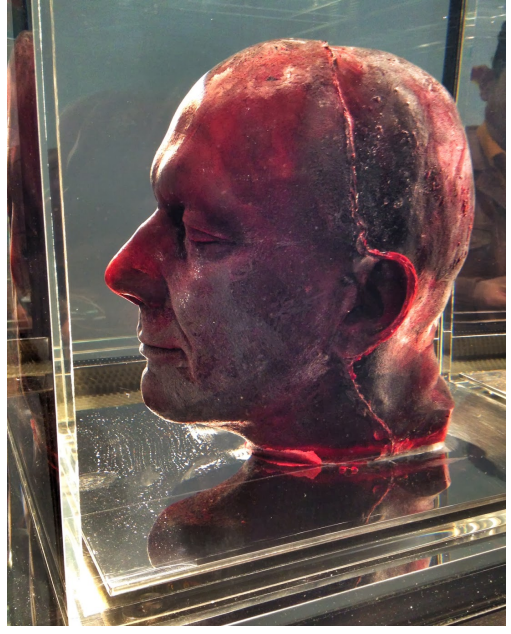

Resim 17. Marc Quinn, Self 
İngiliz sanatçı Quinn çok farklı deneysel bir yol kullanarak otoportre heykelini üretmiştir. İlginç dışavurumcu tarzda yaptığı otoportre heykelinde sanatçı kendi kanını kullanmıştır. Geleneksel malzemenin çok ötesinde kendi kanın alıp, kalıplanıp dondurarak oluşturduğu çalışmasında kanın gerçek kırmızı rengi çalışmanın ifadesini ve gücünü çarpıcı bir şekilde dışavurur (Resim 16-17).

Kendi kanından otoportre büstünü gerçekleştiren Quinn bu şekilde kendilik kavramının hem sembolik hem de gerçek işlevini yerine getirmiştir. Ouinn, alkolik olduğu ve bağımlılık kavramının- bir şeyin takılması ya da hayatta kalabilmek için bir şeye bağlı olması gereken bir şey olduğu için bu çalışmasının muhafazasında elektiriği kullanmıştır. Yaşamını sürdürebilmesi için bağımlı olduğu şeyi kullanması gerektiğine gönderme ve vurgu yaparak eserinin ham maddesi olan kendi donmuş kanın muhafazasında elektiriği kullanmıştır. Her beş yılda bir tekrarlanan bu self çalışma serileri, sanatçının yaşlanmakta olan ve değişen benliklerinin kendi kendine bir portre ve kümülatif dizisidir (Quinn, 1991).

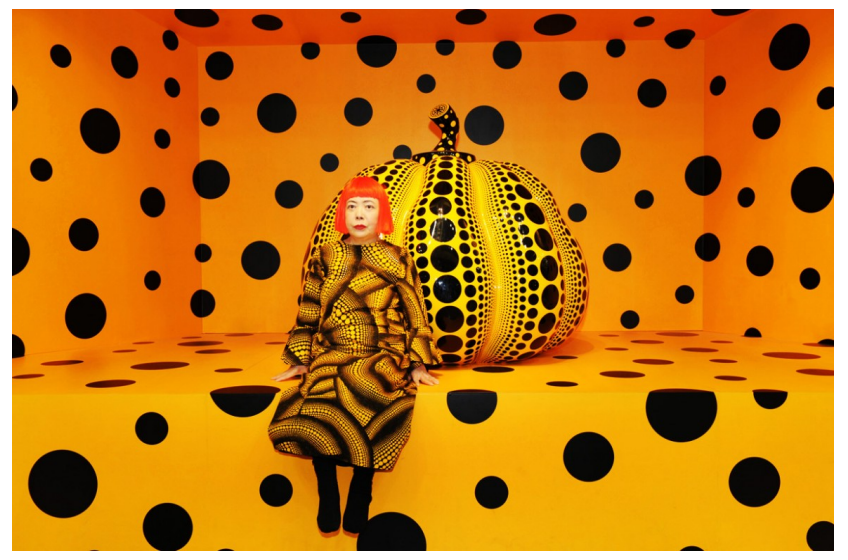

Resim 18. Yayoi Kusama, Balkabă̆ı ile Kusama

Japon sanatçı Kusama, katı aile kuralları içinde büyümüş ve babasının kadınlarla yaşadığı ilişkiler yüzünden cinsel anlamda takıntılı ve isteksiz hale getirmiştir. Kusama 10 yaşına geldiğinde gözünün önündeki bütün her yerde ve bütün nesneleri kaplayan benekler görmeye başlamıştır. Bu her yerde gördügü modern formda parlak renkteki tüm hayatını kapsayan benekleri Kusama'nın imzasını kendi benliğini oluşturmuştur (Resim 18). Amerikalı ressam Georgia O'Keeffe'nin resimlerinden oldukça etkilenen sanatçı kendi isteğiyle yaşantısına bir akıl hastanesinde devam etmektedir. Kusama kendi psikolojik rahatsızlığının onu ve sanatını daha güçlü kıldığına inanmaktadır (Yahşi, 2016).

\section{Sonuç}

Kişinin ifadesinin en etkili ve en yalın halinin direkt ya da dolaylı olarak gösterilmesini konu alan otoportre sanatçıların her daim çalıştıkları bir konu olmuştur. İnsanları birbirinden ayırabilmenin yanı sıra ressamın en kişisel anlatım şekli olan otoportrenin tarihsel gelişim süreçlerine baktığımızda başlangıçta sanatsal bir kaygı gütmekten uzak bir biçimde ortaya konulduğu görülmektedir. Yüzyıllar içinde otoportre farklı sanatsal süreçlerden geçerek içinde bulunduğu dönemin anlayışına göre de farklı biçimsel kimliklere bürünerek bir nevi sanatçının hayatının dışavurumu olmuştur.

Çağdaş sanatta çok yönlü boyutlarla ifade bulan çoğul bir anlatım bulunduğundan dolayı üretilen otoportrelerde geleneksel kuralların ve anlatıların çok ötesinde bir tutum sergilediği görülmüştür. Ayrıca çağdaş sanattaki otoportrelerde tuvalin dışında farklı malzemelerin, fotoğrafın, bedenin kullanımının hem biçimsel hem de düşünsel boyutta farklı ifade biçimlere dönüştügü görülmüsstür. Çağımız sanatında sanatçıların otoportreleri ele alış biçiminde görülen farklarla, sanatın tek yönlü bir yapı olmadığını, estetik anlatıların çoğul bir hal alarak her sanatçı için farklı anlam ve ifade boyutlarına sahip olduğunu söyleyebiliriz. 
Çağdaş sanat anlamında üretilen otoportrelere baktığımızda sadece kişinin kendine benzetim kaygısı taşımadığını görmekteyiz. Sanatçı, kendiyle ilgili olanın yanında hayatta sorgulamak istediklerini bazen dışavurumcu bazen protest bir tavır takınarak ya da tamamen kendi içinden geldiği gibi ifade etmek istemiştir. Çağdaş sanatta bu ifade zenginliği ve serbestliği, kullanılan sanat medyumlarının çeşitliliğiyle otoportre çalışmaları her sanatçı için yüzün ötesinde farklı anlamlar, düşünceler sunarak çok boyutlu bir anlatım diline dönüşmüştür.

\section{Kaynakça}

Akman, K. (2005, 11 Nisan). Orlan'ın suretleri (E. Gezgin, Çev.). İzinsiz Gösteri Dergisi, 37. Erişim adresi: http://www.izinsizgosteri.net/asalsayi37/Kubilay.Akman_37.html

Antmen, A. (2010). 20. yüzyıl batı sanatında akımlar. İstanbul: Sel Yayınc1lık.

Ateş, S. (2015, 11 Ağustos). Tabularla dans Halil Altındere [Blog yazısı]. Erişim adresi: https://sanatkaravani.com/tabularla-dans-halil-altindere/

Balkaya, B. (2015). Kendinden iğrenen sanatçı Tracey Emin [Blog yazısı]. Erişim adresi: http:/therootmag.com/kendinden-igrenen-sanatci-tracey-emin/

Collection online. (t.y.). Hannah Wilke. Erişim adresi: https://www.guggenheim.org/artwork/artist/hannah-wilke

Çarmıklı, B. (2014, 1 Aralık). Anıtların adamı Anselm Kiefer [Blog yazıs1]. Erişim adresi: http://www.banucarmikli.com/anitlarin-adami-anselm-kiefer/

Demirbulak, A. (2007). Çağdaş Türk resminde otoportreler (Doktora Tezi). YÖK tez veri tabanından erişildi (Tez no: 209754).

Ergüven, M. (2002). Yoruma doğru. İstanbul: Yapı Kredi Yayınları.

Heartney, E. (2008). Sanat ve bugün (O. Akınhay, Çev.). İstanbul: Akbank Kültür ve Sanat Yayınları.

İskender, K. (1997). Portre. Eczacıbaşı Sanat Ansiklopedisi içinde (Cilt 3). İstanbul: YEM Yayınevi.

İz, K. (2014 Eylül/Ekim). Çağdaş sanatın asyalı ustaları. Artam Global\&Art Design, (29), 87-96.

Kaynak, T. (2016 Mart/Nisan). Bir akşam yemeği menüsü. Artam Global\&Art Design, (37), 64-156.

Kimmelman, M. (1996, 15 Kasım). Making metaphors of art and bodies. The New York Times. Erişim adresi: https://www.nytimes.com/1996/11/15/arts/making-metaphors-of-art-and-bodies.html

Leppert, R. (2002). Sanatta anlamın görüntüsü (İ. Türkmen, Çev.). İstanbul: Ayrıntı Yayınları.

Quinn, M. (1991). Artworks self 1991-present [Blog yazısı]. Erişim adresi: http://marcquinn.com/artworks/self

Salkur, A. A. (2014). Protest bir tavir olarak otoportre (Yüksek Lisans Tezi). YÖK tez veri tabanından erişildi (Tez no: 372413).

Wilson, M. (2015). Çăgdaşs sanat nasıl okunur. (M. T. Yalım, Çev.). İstanbul: Hayalperest Yayınevi.

Woodal, J., Bond, A., Clark, H. J., Jordanova, L., Koerner, J. L. (2005). The body of the artist, self portrait. London: National Portrait Gallery.

Yahşi, E. (2016, 25 Nisan). Benekler kraliçesi: Yayoi Kusama [Blog yazısı]. http://www.sanatatak.com/view/benekler-kralicesi-yayoi-kusama

Yıldız, S. (2017, 8 Mart). Sanatıyla arsız: Marina Abramović [Blog yazısı]. Erişim adresi: http://arsizsanat.com/sanatiyla-arsiz-marina-abramovic/ 
Yılmaz, M. (2006). Modernizmden Postmodernizme sanat. Ankara: Ütopya Yayınevi.

Yılmaz, İ. (2017, 17 Ağustos). Ergin İnan'ın 50 yılı. Hürriyet. Erişim adresi: http://www.hurriyet.com.tr/ergin-inanin-50-yili-40553041

\section{Resim kaynakçası}

Resim1. Smith, Kiki. (Sanatçı). (1994). Benim Mavi Gölüm. [Fotogravür ve Monoprint]. Erişim adresi: https://www.sartle.com/artwork/my-blue-lake-kiki-smith

Resim 2. Freud, Lucian. (Sanatçı). (1985). Reflection (Otoportre). [Yağlıboya]. Erişim adresi: https://www.tarihnotlari.com/lucian-freud/lucian-freudreflection-kendi-portresi/

Resim 3. İnan, Ergin. (Sanatçı). (2015). Otoportre. [Yağlıboya]. Erişim adresi: http://www.ekolsanatgalerisi.com/?p=1828

Resim 4. Erdok, Neşe. (Sanatçı). (1989). Tanık (Otoportre). [Yağlıboya]. Erişim adresi: $\mathrm{http} / / / \mathrm{www}$.sanatteorisi.com/sanatteorisi.asp?sayfa $=$ Galeri\&icerik=Goster\&id=3327

Resim 5. Fanzhi, Zeng. (Sanatçı). (2007). Maske Serisi. [Yağlıboya]. Erişim adresi: https://www.mutualart.com/ArticlesResults/Zeng\%20Fanzhi\%20mask\%20series?q=Zeng+Fanz $\mathrm{hi}+$ mask + series $\&$ Params $=3130303535362 \mathrm{C} 43757272656 \mathrm{E} 74506167652 \mathrm{C} 322 \mathrm{C} 31$

Resim 6. Minjun, Yue. (Sanatçı). (2013). Mavi Gök Beyaz Bulut [Yağlıboya]. Erişim adresi: http://www.artnet.com/artists/yue-minjun/white-cloud-in-blue-sky-aIydHDNBEw4qlwfamjLfJYg2

Resim 7. Kiefer, Anselm. (Sanatçı). (1996). Gecenin Emirleri [Akrilik Ve Gomalak Emülsiyon]. Erişim adresi: https://www.artsy.net/artwork/anselm-kiefer-the-orders-of-the-night-die-ordender-nacht

Resim 8. Sherman, Cindy. (Sanatç1). (2000). İsimsiz 351 [Fotoğraf]. Erişim adresi: https://www.wikiart.org/en/cindy-sherman/untitled-351-2000

Resim 9. Sherman, Cindy. (Sanaţ̧1). (2000). Ísimsiz 397. [Fotoğraf]. Erişim adresi: https://www.thebroad.org/art/cindy-sherman/untitled-397

Resim 10. Altındere, Halil. (Sanatç1). (1997). Tabularla Dans. [Fotoğraf ve Yerleştirme]. Erişim adresi: http://sanatkaravani.com/tabularla-dans-halil-altindere/

Resim 11. Neşat, Şirin. (Sanatçı). (1997). Allah'ın Kadınları [Fotoğraf]. Erişim adresi: http://sanatkaravani.com/yuzlerin-otesinde-olan-kadinlar-allahin-kadinlari-shrin-neshat/

Resim 12. Wilke, Hannah. (Sanatçı). (1974-79). Starlaştırılan obje serisi [Fotoğraf]. Erişim adresi: https://www.moma.org/collection/works/102432

Resim 13. Abromoviç, Marina. (Sanatçı). (2010). Sanatçı aramızda [Performans]. Erişim adresi: https://giphy.com/gifs/contemporary-art-VIh95kNQYEmPe

Resim 14. Emin, Tracey. (Sanatçı). (1998). Benim yatağım. [Fotoğraf ve Yerleştirme]. Erişim adresi: https://www.independent.co.uk/arts-entertainment/art/news/tracey-emins-bed-returns-to-thetate-after-record-sale-9636261.html

Resim 15. Carnal, Orlan. (Sanatçı). (1990). Saint Orlan's reincarnation [Fotoğraf ve Yerleştirme]. Erişim adresi: https://chromaticspiral.wordpress.com/tag/cindy-sherman/

Resim 16. Quinn, Marc. (Sanatç1). (2006). Self [Heykel]. Erişim adresi: http://marcquinn.com/artworks/single/self-20061 
Resim17. Quinn, Marc. (Sanatçı). (2011). Self [Heykel]. Erişim adresi: http://marcquinn.com/artworks/single/self-20111

Resim 18. Kusama, Yayoi. (Sanatçı). (2010). Balkabă̆ı ile Kusama [Enstelasyon]._Erişim adresi: $\mathrm{http}: / / \mathrm{www}$. redonline.co.uk/travel/what-s-on/best-art-exhibitions-in-the-world 